\title{
Pituitary Adenomas In Childhood and Adolescence
}

\author{
G. Maira and C. Anile
}

\begin{abstract}
Pituitary adenomas are considered rare tumors in the pediatric age group. The natural history in this age group is not well known, although many authors have suggested that pituitary adenomas in children tend to be extrasellar and invasive and that a subfrontal approach is mandatory in the majority. Our patients were part of a surgical series of 356 adenomas of all ages. We have divided these cases into three groups: the first consists of patients operated on before the age of 21 years ( 52 cases, $15 \%$ ); the second, patients treated after the age of 20 but in whom the clinical history started before 21 years (52 cases, $15 \%$ ); the third, patients with surgery and symptoms after 20 years (252 cases, $70 \%$ ). Transsphenoidal removal of the adenomas was the initial procedure in all but one of these cases; a few required a second intracranial operation. In our series, pituitary adenomas in children were not more invasive than in other age groups.

RÉSUMÉ: Adénomes pituitaires de l'enfance et de l'adolescence Les adénomes hypophysaires sont considérés comme des tumeurs survenant rarement dans les groupes d'âge pédiatrique. De plus, l'évolution naturelle de cette maladie n'est pas bien connue dans cette tranche d'âge, bien que beaucoup d'auteurs suggèrent que les adénomes hypophysaires de l'enfant ont tendance à être extrasellaires, invasifs, et qu'une approche chirurgicale sous-frontale est indispensable dans la plupart des cas. Les patients faisant l'objet de la présente étude appartiennent à une série de 356 adénomes de tous âges opérés. Afin d'obtenir des informations sur les aspects particuliers des adénomes pédiatriques, nous avons subdivisé ces tumeurs en trois groupes: le premier comprend des patients opérés avant l'âge de 21 ans (52 cas, 15\%), le second inclut des patients traités après l'âge de 20 ans mais chez lesquels l'histoire de la maladie avait débuté avant l'âge de 21 ans, et le troisième groupe réunit les patients ayant été opérés et étant devenus symptomatiques après l'âge de 20 ans (252 cas, $70 \%)$. L'exérèse transsphénoïdale de l'adénome fut l'abord choisi dans tous les cas sauf un: seulement quelques patients dûrent subir une intervention intracrânienne dans un second temps. Dans notre série, les adénomes hypophysaires de l'enfant présentent une incidence d'invasivité qui n'est pas supérieure à celle d'autres catégories d'âges. Comme pour les adénomes hypophysaires de l'adulte, un diagnostic précoce est essentiel pour réduire l'incidence des extensions suprasellaires et pour augmenter les chances d'efficacité du traitement chirurgical.
\end{abstract}

Can. J. Neurol Sci. 1990; 17:83-87

Pituitary adenomas are considered rare tumors in the pediatric age group. ${ }^{1,2.3}$ In many large series they account for only $1 \%$ to $10 \%$ of adenomas of all ages. ${ }^{4-11}$ Some of these series include not only patients operated on in the pediatric age but also cases in whom the onset of symptoms was before the age of 20 years. $4,8,11,12$ The natural history of the disease in this age group is not well known, although many authors state that pituitary adenomas in children tend to be extrasellar and invasive 4,5 ,$7,13,14.15$ and that a subfrontal approach is mandatory in the majority. 5.14 This report describes the preoperative findings, the surgical management and the follow-up of pituitary adenomas in a pediatric series treated at the Catholic University of Rome in the period July 1976 to December 1986.

\section{Clinical Material}

Our pediatric patients belong to a total series of 356 operated adenomas in cases of all ages (Table 1).

As in the majority of clinical series, 16,17 the Prolactin (PRL) secreting adenomas are most common $(45 \%)$ followed by the
Growth Hormone (GH) secreting adenomas (26\%), by nonsecreting adenomas $(24 \%)$ and by Adreno-Corticotrophic Hormone (ACTH) secreting adenomas (5\%). The exact diagnosis was based on preoperative hormonal and radiological data and histological verification using immunohistochemical hormone staining. The anatomo-radiological alterations of the sella turcica are classified according to Hardy and Vezina. ${ }^{18}$ In all the patients a pre- and post-surgical hormonal study was performed. In particular we have analyzed all the pituitary functions in basal conditions and with dynamic tests. The modalities of sam-

Table 1: Pituitary Adenomas (July 1976 - December 1986)

\begin{tabular}{lrrr}
\hline & Females & Males & \multicolumn{1}{c}{ Total } \\
\hline PRL - secreting adenomas & $136(38 \%)$ & $24(7 \%)$ & $160(45 \%)$ \\
GH - secreting adenomas & $58(16 \%)$ & $35(10 \%)$ & $93(26 \%)$ \\
ACTH - secreting adenomas & $13(4 \%)$ & $5(1 \%)$ & $18(5 \%)$ \\
Non - secreting adenomas & $49(14 \%)$ & $36(10 \%)$ & $85(24 \%)$ \\
\hline TOTAL & $256(72 \%)$ & $100(28 \%)$ & $356(100 \%)$ \\
\hline
\end{tabular}


'Table 2: Pituitary Adenomas (July 1976 - December 1986)

\begin{tabular}{lrcc}
\hline & $\begin{array}{c}\text { Surgery before } \\
\text { 21 years }\end{array}$ & $\begin{array}{c}\text { Symptoms before } \\
\text { 21 years }\end{array}$ & $\begin{array}{c}\text { Symptoms after } \\
\text { 20 years }\end{array}$ \\
\hline PRL & $22(6 \%)$ & $45(13 \%)$ & $93(26 \%)$ \\
GH & $8(3 \%)$ & $6(2 \%)$ & $79(22 \%)$ \\
ACTH & $3(1 \%)$ & $1(<1 \%)$ & $14(4 \%)$ \\
Non-secr. & $19(5 \%)$ & - & $66(18 \%)$ \\
\hline TOTAL & $52(15 \%)$ & $52(15 \%)$ & $252(70 \%)$ \\
\hline
\end{tabular}

ple collection and the radioimmunoassay (RIA) method used for hormone determination were reported in our previous papers. ${ }^{19,20}$

In order to obtain information on the particular aspects of the adenomas in pediatric age we divided our patients into three groups (Table 2): the first included 52 patients (15\%; 18 boys and 34 girls aged from 7 to 20 years) operated on before the age of 21 years; the second, 52 patients $(15 \% ; 2$ males and 50 females aged from 21 to 40 years) treated after the age of 21 but in whom the clinical symptoms appeared before the age of 21 years; the third group of 252 patients $(70 \%$; 80 men and 172 women) had symptoms and surgery after the age of 20 years. The frequency and type of hypersecretion in children are similar to the distribution found in adults with a preponderance of PRL secreting adenomas.

We analyzed the anatomo-surgical features in relationship to normalization of the clinico-hormonal status.

\section{Surgical Management}

Transsphenoidal removal of the adenoma, using microsurgical techniques, was the procedure of choice in almost all these cases. The indications for this procedure in young patients are the same as in adults. In order to remove pituitary tumors through the transsphenoidal approach, they must be totally intrasellar or have a regular suprasellar expansion. While the technical procedure is the same as that used in adult patients ${ }^{16}$ some problems relate to its application in young patients. First of all a concha type sphenoidal sinus filled entirely by cancellous bone is frequently encountered. Consequently, the use of the diamond drill is required, along with continuous application of bone wax to reduce the oozing of blood. This procedure demands great caution in exposing the sella, although with experience this can be adequately and safely accomplished. A second point is the existence of important venous channels (intracavernous or coronal sinuses) connecting the two cavernous sinuses which are located in the double layer of the anterobasal dura. The removal of the pituitary tumor can be made difficult by continuous intraoperative bleeding if these veins are opened. Topical application of gelfoam and thrombin or bipolar coagulation of the dura can stop the bleeding. The adenoma may be totally enclosed by normal pituitary gland which must be incised to disclose it. After the complete removal of all the tumor, the residual cavity walls are composed of normal tissue. In other cases the adenoma may appear immediately following the opening of the dura and only after its removal is normal gland recognized. The differentiation between adenoma and normal gland is helped by intraoperative pathological examination. ${ }^{21}$
Four cases, after a transsphenoidal approach, required a second intracranial operation. In only one case was the subfrontal approach utilized as the first and only surgical procedure.

\section{ResultS}

\section{PRL-secreting Adenomas}

Twenty-two (14\%) of the 160 patients operated on for PRLsecreting adenomas were under 21 years; $45(28 \%)$ were operated on after the age of 20 years but their clinical symptoms had started before the age of 21 years; in 93 patients $(58 \%)$, the clinical history started after the age of 20 . The clinical details of these patients together with the incidence of suprasellar expansion, visual defect and invasive characteristics are reported (Table 3).

All the patients with PRL-secreting adenomas were operated on using a transsphenoidal approach.

Normalization of the PRL basal values, without signs of tumor recurrence during a follow-up ranging from 1 to 9 years,

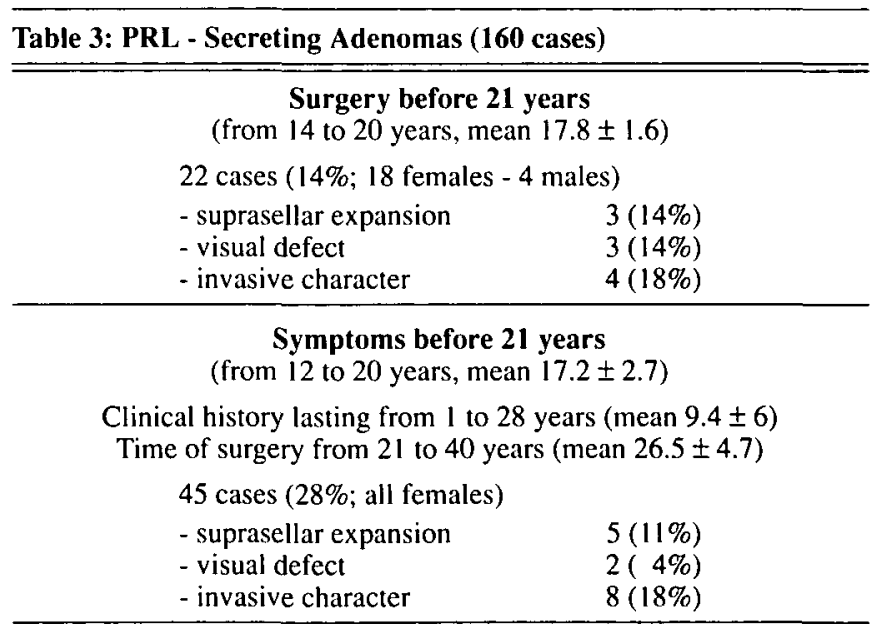

Symptoms after 20 years

Time of surgery from 21 to 62 years (mean $34.2 \pm 8.8$ )

93 cases (58\%; 73 females - 20 males)

$\begin{array}{ll}\text { - suprasellar expansion } & 27(29 \%) \\ \text { - visual defect } & 19(20 \%) \\ \text { - invasive character } & 29(31 \%)\end{array}$

\begin{tabular}{|c|c|c|}
\hline \multicolumn{3}{|c|}{$\begin{array}{l}\text { Table 4: PRL - Secreting Adenomas (139 cases) } \\
\text { Normalization of PRL levels }(<21 \mathrm{ng} / \mathrm{ml})\end{array}$} \\
\hline Level & Preoperative & Postoperative \\
\hline \multicolumn{3}{|c|}{ Surgery before 21 years } \\
\hline $\begin{array}{r}21-250 \mathrm{ng} / \mathrm{ml} \\
251-500 \mathrm{ng} / \mathrm{ml} \\
>500 \mathrm{ng} / \mathrm{ml}\end{array}$ & $\begin{array}{l}\text { ( } 11 \text { cases) } \\
\text { ( } 4 \text { cases) } \\
\text { ( } 3 \text { cases })\end{array}$ & $\begin{array}{c}11(100 \%) \\
2(50 \%) \\
-\end{array}$ \\
\hline \multicolumn{3}{|c|}{ Symptoms before 21 years } \\
\hline $\begin{array}{r}21-250 \mathrm{ng} / \mathrm{ml} \\
251-500 \mathrm{ng} / \mathrm{ml} \\
>500 \mathrm{ng} / \mathrm{ml}\end{array}$ & $\begin{array}{l}(22 \text { cases }) \\
(9 \text { cases }) \\
(9 \text { cases })\end{array}$ & $\begin{array}{r}16(73 \%) \\
5(55 \%) \\
3(33 \%) \\
\end{array}$ \\
\hline \multicolumn{3}{|c|}{ Symptoms after 20 years } \\
\hline $\begin{array}{r}21-250 \mathrm{ng} / \mathrm{ml} \\
251-500 \mathrm{ng} / \mathrm{ml} \\
>500 \mathrm{ng} / \mathrm{ml}\end{array}$ & $\begin{array}{l}(36 \text { cases }) \\
(10 \text { cases }) \\
(35 \text { cases })\end{array}$ & $\begin{array}{r}31(86 \%) \\
3(30 \%) \\
4(11 \%)\end{array}$ \\
\hline
\end{tabular}


Table 5: PRL - Secreting Adenomas (139 cases)

Normalization of PRL levels $(<21 \mathrm{ng} / \mathrm{ml})$

\begin{tabular}{|c|c|c|}
\hline Grade* & Preoperative & Postoperative \\
\hline \multicolumn{3}{|c|}{ Surgery before 21 years } \\
\hline 1 & ( 10 cases $)$ & $7(70 \%)$ \\
\hline 11 & ( 7 cases) & $6(86 \%)$ \\
\hline III & (- cases) & - \\
\hline IV & ( 1 case ) & - \\
\hline \multicolumn{3}{|c|}{ Symptoms before 21 years } \\
\hline I & (17 cases) & $15(88 \%)$ \\
\hline II & (19 cases) & $9(47 \%)$ \\
\hline III & ( 3 cases) & - \\
\hline IV & ( 1 case $)$ & - \\
\hline \multicolumn{3}{|c|}{ Symptoms after 20 years } \\
\hline I & (33 cases) & $28(85 \%)$ \\
\hline II & (33 cases) & $10(30 \%)$ \\
\hline III & ( 3 cases) & - \\
\hline IV & (12 cases) & - \\
\hline
\end{tabular}

* Radiological classification of Hardy and Vézina: ${ }^{18}$

(Grade I: microadenoma, normal sized sella;

Grade II: enlarged sella turcica;

Grade III: local invasion of sellar floor;

Grade IV: diffuse invasion of sella).

Table 6: GH - Secreting Adenomas (93 cases)

Surgery before 21 years

(from 7 to 20 years, mean $15.7 \pm 4.8$ )

8 cases ( $9 \% ; 4$ females -4 males)

- suprasellar expansion $\quad 6(75 \%)$

- visual defect $4(50 \%)$

- invasive character $4(50 \%)$

Symptoms before 21 years

(from 7 to 20 years, mean $15.2 \pm 4.7$ )

Clinical history lasting from 3 to 31 years (mean $11 \pm 10.9$ )

Time of surgery from 21 to 38 years (mean $26.2 \pm 6.9$ )

6 cases ( $7 \% ; 4$ females -2 males)

- suprasellar expansion $\quad 2(33 \%)$

- visual defect $1(16 \%)$

- invasive character $2(33 \%)$

Symptoms after 20 years

Time of surgery from 23 to 68 years (mean $45.5 \pm 10.3$ )

79 cases ( $84 \%$; 50 females - 29 males)

$\begin{array}{ll}\text { - suprasellar expansion } & 15(19 \%) \\ \text { - visual defect } & 15(19 \%)\end{array}$

- invasive character

$25(32 \%)$

is analyzed in 139 patients by comparing groups with similar preoperative PRL basal values (Table 4) or sellar grades (Table 5).

\section{GH-secreting Adenomas}

Eight $(9 \%)$ of the 93 patients operated on for $\mathrm{GH}$-secreting adenomas were under 21 years; six $(7 \%)$ were operated on after the age of 20 years but had a clinical history starting before age 21 ; in 79 patients $(84 \%)$ the clinical history started after the age of 20. The clinical details of these patients, together with the incidence of suprasellar expansion, visual defect and invasive characteristics, are reported in Table 6.
All the pediatric patients except one were operated on using a transsphenoidal approach. Four required a second intracranial approach, a few months later to complete the excision. Normalization of the clinical picture was observed in all but one in whom the tumor quickly recurred and who was therefore treated with radiotherapy. In one case with a markedly preponderant suprapituitary location of the tumor (Figure 1) a subfrontal approach was used initially to completely remove it. The possibility of achieving long-lasting normalization of the $\mathrm{GH}$ basal values, without signs of tumor recurrence, is analyzed in 79 patients comparing groups with similar sellar grade (Table 7).

\section{ACTH-secreting Adenomas}

Three (17\%) of the 18 patients operated on for an ACTHsecreting adenoma were under 21 years; one $(5 \%)$ was operated on after the age of 20 years but the clinical symptoms started earlier; in 14 patients $(78 \%)$ the clinical history started later. The clinical details of these patients are reported in Table 8 . All these adenomas lacked suprasellar expansion or invasive characteristics. All patients of this group were operated on using a transsphenoidal approach. None of them required a frontal
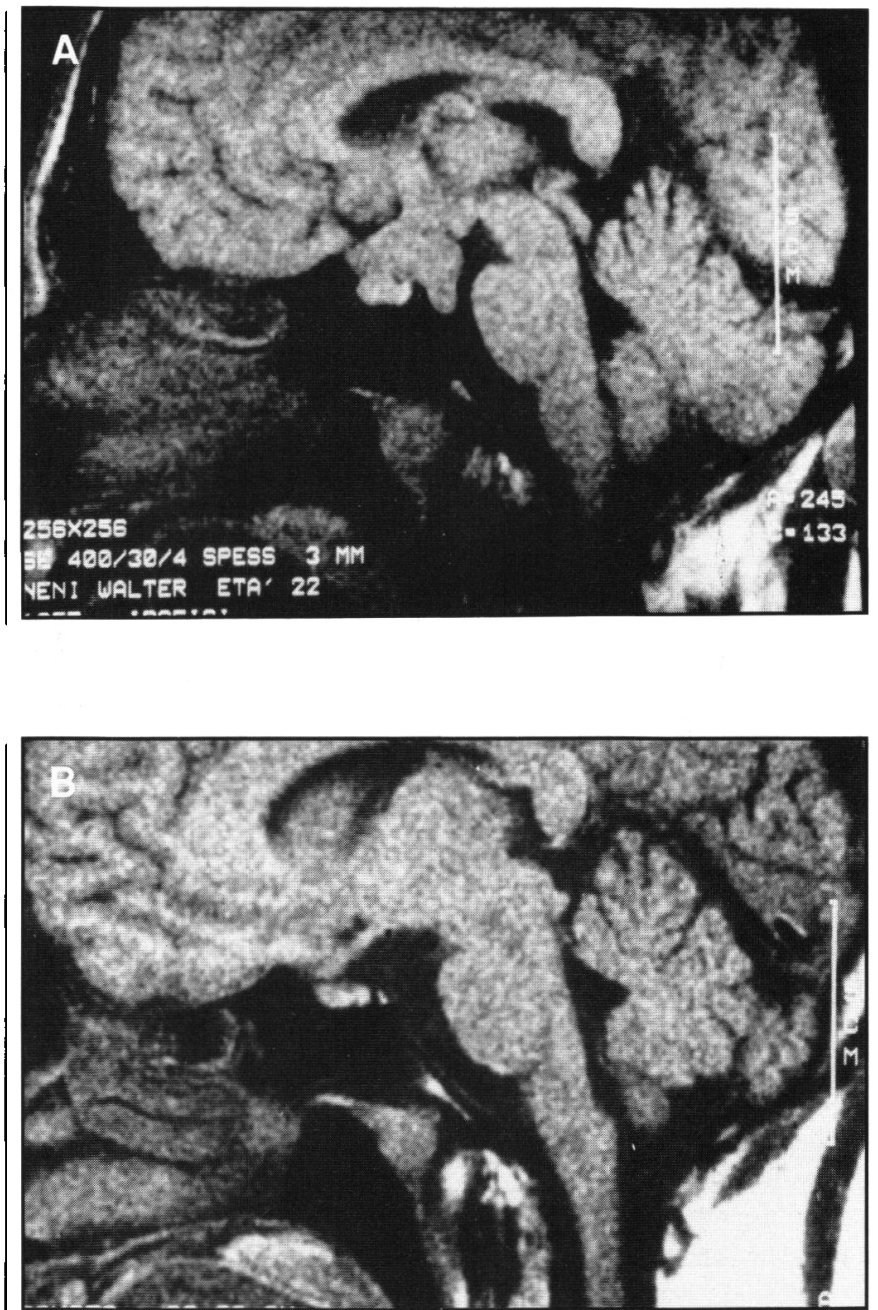

Figure I -NMR picture showing the exclusively suprasellar localization of a $G H$-secreting adenoma in a pediatric patient (see text). $A=$ before surgery. $B=$ after surgery. 
Table 7: GH - Secreting Adenomas (79 cases)

Postoperative normalization of $\mathrm{GH}$ levels $(<5 \mathrm{ng} / \mathrm{ml})$

\begin{tabular}{|c|c|c|}
\hline Grade & Preoperative & Postoperative \\
\hline \multicolumn{3}{|c|}{ Surgery before 21 years } \\
\hline I & ( 2 cases) & $2(100 \%)^{*}$ \\
\hline II & ( 4 cases) & $3(75 \%)$ \\
\hline III & ( 2 cases) & - \\
\hline IV & (- cases) & - \\
\hline \multicolumn{3}{|c|}{ Symptoms before 21 years } \\
\hline I & ( 1 case ) & $1(100 \%)$ \\
\hline II & ( 5 cases) & $3(60 \%)$ \\
\hline III & (- cases) & - \\
\hline IV & (- cases) & - \\
\hline \multicolumn{3}{|c|}{ Symptoms after 20 years } \\
\hline 1 & ( 9 cases $)$ & $9(100 \%)$ \\
\hline Il & (44 cases) & $35(80 \%)$ \\
\hline III & ( 3 cases) & $2(66 \%)$ \\
\hline IV & ( 9 cases) & $3(33 \%)$ \\
\hline
\end{tabular}

* One patient with an exclusively suprasellar localized adenoma.

Table 8: ACTH - Secreting Adenomas ( 18 cases)

Surgery before 21 years

(from 13 to 17 years, mean $14.3 \pm 2.3$ )

3 cases (17\%; 1 female - 2 males)

Symptoms before 21 years

(at 19 years)

Clinical history lasting from 11 years

Age at surgery - 30 years

1 case $(5 \%$; female $)$

Symptoms after 20 years

Age at surgery - 25 to 70 years (mean $43.07 \pm 12.39$ )

14 cases $(78 \% ; 1$ female -3 males $)$

approach operation. In all, normalization of the ACTH basal values and blood cortisol levels, without signs of tumor recurrence, were observed during a follow-up of at least one year.

\section{Non-secreting Adenomas}

Nineteen (22\%) of the 85 patients operated on for nonsecreting adenomas were under 21 years. No patient older than 20 years but with earlier onset of symptoms was found. In the remaining 66 patients $(78 \%)$, the clinical history started after the age of 20. The clinical details are reported in Table 9. All were operated on using a transsphenoidal approach. None required a frontal approach.

\section{Discussion}

Pituitary adenomas have traditionally been regarded as uncommon tumors in children and adolescents, with a high tendency to involve contiguous and suprasellar structures. A subfrontal approach has been recommended in the majority of these cases.5.14 Our analysis shows that these adenomas are less rare in childhood and adolescence than was previously suspected. In the $30 \%$ of our total series the growth of the pituitary tumor started before the age of 21 years. In these patients, the most frequent tumors were the prolactinomas $(65 \%)$, followed by the
Table 9: Non - Secreting Adenomas (85 Cases)

\begin{tabular}{|c|c|}
\hline \multicolumn{2}{|c|}{$\begin{array}{c}\text { Surgery before } 21 \text { years } \\
\text { (from } 7 \text { to } 18 \text { years, mean } 12 \pm 3.7 \text { ) }\end{array}$} \\
\hline \multicolumn{2}{|c|}{19 cases $(22 \% ; 11$ females -8 males $)$} \\
\hline $\begin{array}{l}\text { - suprasellar expansion } \\
\text { - visual defect } \\
\text { - invasive character }\end{array}$ & $\begin{array}{l}1(5 \%) \\
1(5 \%)\end{array}$ \\
\hline \multicolumn{2}{|c|}{$\begin{array}{c}\text { Surgery after } 20 \text { years } \\
\text { (from } 23 \text { to } 82 \text { years, mean } 50 \pm 14.8 \text { ) }\end{array}$} \\
\hline \multicolumn{2}{|c|}{66 cases $(78 \% ; 38$ females -28 males) } \\
\hline $\begin{array}{l}\text { - suprasellar expansion } \\
\text { - visual defect } \\
\text { - invasive character }\end{array}$ & $\begin{array}{l}45(68 \%) \\
42(64 \%) \\
25(38 \%)\end{array}$ \\
\hline
\end{tabular}

non-secreting (18\%), $\mathrm{GH}$ secreting (13\%) and $\mathrm{ACTH}$ secreting $(4 \%)$. In our prolactinomas, $42 \%$ had the onset of symptoms in childhood or adolescence, much more than the $10 \%$ reported by Wilson and Dempsey ${ }^{22}$ or the $11 \%$ by Lucas et al. 8

We noted that invasiveness was more frequently observed in older people $(31 \%)$ than younger $(18 \%)$. The same is true for suprasellar expansion and visual defect. The possibility of achieving a cure was higher in younger patients (see Tables 4 and 5). These data do not confirm the observation of Ludecke et $\mathrm{al}^{9}$ who reported that $75 \%$ of pediatric PRL-secreting tumors were invasive and only $13 \%$ of cases had hormonal normalization.

$\mathrm{GH}$ secreting tumors were the only adenomas in our series in which a tendency to the suprasellar expansion and an invasive character was more common in children. This peculiarity has been commented upon by other authors such as Ludecke et al ${ }^{9}$ who reported suprasellar expansion in $86 \%$ and invasiveness in $57 \%$. Similarly Laws et al ${ }^{7}$ reported that $67 \%$ of pediatric tumors were macroadenomas and $33 \%$ were invasive. Only in this group of patients were intracranial approaches required. Only one patient with $\mathrm{GH}$ invasive adenoma in our series required a radiotherapic treatment which is similar to data in the literature. ${ }^{9}$ Postoperative normalization of hormone secretion was high in all the groups of patients, apparently unrelated to age.

Among our patients with a non-secreting adenoma we have operated on 19 cases younger than 21 years, with a range between 7 and 18 years. Many of our cases with non-secreting adenomas belong to a series which was described 21.23 as growth retardation due to $\mathrm{GH}$ deficit. The recognition of this very early endocrinological sign explains the absence of suprasellar expansion and invasiveness in these younger patients compared to the older ones. In the latter the diagnosis was usually possible only after the appearance of neurological symptoms. This seems to indicate, at least for the non-secreting adenomas, that in the majority of cases the expansion and invasiveness of the tumor is not dependent on a peculiar biological characteristic. The discrepancies between our results and the literature which reports a high incidence of large and invasive lesions in childhood and adolescence 8.9 can be due to the time-lag between the onset of symptoms and the time of treatment. $5,8,11,12$ Our data on nonsecreting tumors indicate that in prepubertal children, a progressive growth failure and an isolated reduction of $\mathrm{GH}$ reserve can be an important initial sign of an expanding lesion in the sellar region. The relevance of this sign to the early diagnosis of pitu- 
itary tumors in the prepubertal age was noted by Lucas et al ${ }^{8}$ and by Barrio et al. ${ }^{12}$ In older female children a delayed or absent menarche with a modification of PRL secretion are further endocrinological signs of tumors.

Transsphenoidal resection is the procedure of choice for the management of pituitary adenomas in children. In all our cases, an excellent clinical response was obtained with minimal morbidity, no mortality, and preservation in all the cases of normal pituitary tissue including the pituitary stalk. In only a few cases of $\mathrm{GH}$ adenomas was a second intracranial procedure required which resulted in all but one in the complete removal of the adenoma.

Radiation therapy in our opinion is never indicated as initial treatment. It is reserved for patients with recurrent lesions who show clinical progression. In our series it was used only once.

The analysis of our data shows that these tumors are less rare and invasive than was previously thought. The earlier detection of small adenomas is probably the explanation of these apparent differences. Improvement in neuroradiology and the advent of radio-immunoassay methods have permitted earlier diagnosis. In agreement with the previous literature, we found no histological differences between invasive and enclosed adenomas. The term invasive simply represents the involvement of contiguous structures and does not imply increased malignancy. $5,13,14$

For children as with adults, early diagnosis is essential in order to reduce the incidence of local extension and increase the efficacy of surgical treatment.

\section{REFERENCES}

1. Costin G. Endocrine disorders associated with tumors of the pituitary and hypothalamus. Pediatr Clin North Am 1979; 26: 15-31.

2. Dastur DK, Lalitha US. Pathological analysis of intracranial spaceoccupying lesions in 1,000 cases including children. Pituitary adenomas, developmental tumors, parasitic and developmental cysts. J Neurol Sci 1972; 15: 397-427.

3. David M, Bernard-Weil E, Pradat P. Adénomes hypophisaires de l'enfant. Revue Neurol 1962; 106: 334-336.

4. Fraioli B, Ferrante L, Celli P. Pituitary adenomas with onset during puberty. J Neurosurg 1983; 59: 590-595.

5. Gaini SM, Giovannelli M, Forni C, et al. Pituitary adenomas in infancy and childhood. In: Villani R, Giovannelli M, Gaini SM, eds. Modern Problems in Paediatrics. Basel: Karger 1977; 220225.

6. Koos WT, Miller MH. Intracranial tumors of infants and children. Stuttgart: G. Thieme Verlag 1971; 213-220.
7. Laws ER, Scheithauer BW, Groover RV. Pituitary adenomas in childhood and adolescence. Prog Exp Tumor Res. Basel: Karger 1987; 359-361.

8. Lucas $\mathrm{C}$, Guibout M, Jaquet $\mathrm{P}$, et al. Aspects diagnostiques et évolutifs de l'adénome à prolactine chez l'enfant. Arch Fr Pediatr 1980; 37: 79-86.

9. Ludecke DK, Herrmann HD, Schulte FJ. Special problems with neurosurgical treatment of hormone-secreting pituitary adenomas in children. Prog Exp Tumor Res. Basel: Karger 1987: 362370.

10. Odom GL, Davis $\mathrm{CH}$, Woodhall B. Brain tumors in children. Clinical analysis of 164 cases. Pediatrics 1956; 18: 856-870.

11. Richmond IL, Wilson CB. Pituitary adenomas in childhood and adolescence. J Neurosurg 1978; 49: 163-168.

12. Barrio R, Roger M, Chaussain J-L, et al. Les adénomes hypophysaires à prolactine de l'enfant et de l'adolescent. Arch Franc Pediat 1979; 36, 8: 785-793.

13. Martins A, Hayes GJ, Kempe LG. Invasive pituitary adenomas. J Neurosurg 1965; 22: 268-276.

14. Ortiz-Suarez H, Erickson DL. Pituitary adenomas of adolescents. J Neurosurg 1975; 43: 437-439.

15. Weinberger LM, Adler FH, Grant FC. Primary pituitary adenoma and the syndrome of the cavernous sinus. A clinical and anatomic study. Arch Ophthalmol 1940; 24: 1197-1236.

16. Hardy J. Transsphenoidal microsurgical removal fo pituitary microadenoma. In: Krayenbuhl H, Maspes, PE and Sweet WH. eds. Progress in Neurological Surgery. Basel: Karger 1975; 200216.

17. Wilson CB. A decade of pituitary microsurgery. The Herbert Olivecrona lecture. J Neurosurg 1984; 61: 814-833.

18. Hardy J, Vezina JL. Transsphenoidal neurosurgery of intracranial neoplasm. In: Thompson RA and Greene JR, eds. Advances in Neurology. New York: Raven Press 1976; 261-264.

19. Barbarino A, De Marinis L, Maira G, et al. Serum prolactin response to thyrotropin-releasing honnone and metoclopramide in patients with prolactin-secreting tumors before and after transsphenoidal surgery. J Clin Endocrinol Metab 1978; 47: 1148-1151.

20. De Marinis L, Mancini A, Maira G, et al. Postoperative evaluation of dopaminergic tone in prolactinoma patients. 11. Plasma thyrotropin response to metoclopramide. J Clin Endocrinol Metab 1984; 58: 405-409.

21. Maira G, Di Rocco C, Borrelli P, et al. Pituitary microadenomas in children: a cause of growth failure. J Microsurg 1980; 1: 276287.

22. Wilson CB, Dempsey LC. Transsphenoidal microsurgical removal of 250 pituitary adenomas. J Neurosurg 1978; 48: 13-22.

23. Di Rocco C. Maira G, Borrelli P. Pituitary microadenomas in children. Child's Brain 1982; 9: 165-178. 